\title{
Microstructural Characterization of Antimony Modified Carbidic Austempered Ductile Iron
}

\author{
Barnabas Abel. A. ${ }^{1}$, Oyetunji Akinlabi ${ }^{1}, \&$ Seidu S. O. ${ }^{1}$ \\ ${ }^{1}$ Department of Metallurgical and Materials Engineering, Federal University of Technology, Akure. Ondo State, \\ Nigeria \\ Correspondence: Barnabas Abel. A., Department of Metallurgical and Materials Engineering, Federal University \\ of Technology, Akure. Ondo State, Nigeria. E-mail: barnabelad0110@gmail.com
}

Received: February 26, 2019

Accepted: March 23, 2019

Online Published: April 30, 2019

doi: $10.5539 /$ jmsr.v8n2p36

URL: https://doi.org/10.5539/jmsr.v8n2p36

\begin{abstract}
In this research, Scanning Electron Microscope (SEM) analysis was conducted on the produced antimony modified carbidic austempered ductile iron for agricultural implement production. Six different alloys of carbidic austempered ductile iron with varying micro quantities of antimony elements were produced. The produced alloys were heated to austenitic temperature of $910^{\circ} \mathrm{C}$, held at this temperature for 1 hour, finally subjected to austempering temperatures of $300^{\circ} \mathrm{C}$ and $325^{\circ} \mathrm{C}$ for periods of 1-3 hours. The SEM in conjunction with XRD and EDS was used for the analysis. Microstructural phase morphology, phase constituents and phase compositions were viewed with SEM, XRD and EDS respectively. The results show that various phases such as spiky graphite, blocky carbides, granular carbide, pearlite and ausferrite matrix. The XRD pattern revealed some compounds such as $(\mathrm{Fe}, \mathrm{Cr})_{3} \mathrm{C}$, (primary carbide), $\mathrm{Cr}_{6} \mathrm{C}_{23}$ (few secondary carbide), $\left(\mathrm{NiFe}_{2} \mathrm{O}_{4}\right)$, chromite $\left(\mathrm{FeCr}_{2} \mathrm{O}_{4}\right), \mathrm{Cr}_{7} \mathrm{C}_{3}$ (few eutectic carbide) and $\mathrm{Cr}_{3} \mathrm{Ni}_{2}$. In conclusion, it was observed in terms of morphology that chunky graphite, blocky carbide and pearlite phases were present in the cast carbidic ductile iron (CDI) without antimony addition. The CDI with varying quantities of antimony additions shows spiky graphite, granular carbides and pearlite matrix. After the samples were subjected to austempering processes, all the phases were found to be intact except the pearlite phase that transformed to ausferrite phase. The antimony element in the alloys was seen to promote the formation of pearlite phase intensively. The hardness of the samples increases as the antimony addition increases from $0.096 \mathrm{wt}$ \% to $0.288 \mathrm{wt}$.\% owing to the increase in pearlite phase, while the impact toughness reaches relatively high level, when $0.288 \mathrm{wt} . \%$ antimony was added, probably due to the refinement of graphite nodules. All the results obtained showed that appropriate content of antimony addition plays an important role in increasing the nucleation rate of graphite nodules, and also lead to improvement in carbide formation thereby providing good balance between wear and impact properties.
\end{abstract}

Keywords: Carbidic Austempered Ductile Iron, Austempering Temperatures of $300^{\circ} \mathrm{C}$ and $325^{\circ} \mathrm{C}$, Spiky Graphite Phase, Morphology, Granular-, Blocky Carbide and Antimony Content

\section{Introduction}

Cast iron has been popular and important structural material since the technology for melting iron was developed in the 1700s (Tiedje, 2010). In the late 1950s and early 1960s, ductile iron has been rated as a high-quality cast iron material, but it is a material that demands much careful control with raw materials and processes than other cast irons (Tiedje, 2010). As a result of this, many foundry engineers see it as a complex and unpredictable ferrous metal to produce as small variations in the raw materials quality will lead to debilitation of the quality of the casting. Desire for high quality engineering materials make it imperative for production of cast iron with enhanced properties (Gumienny, 2013).

An improved property obtained in ductile iron is as a result of spheroid shape of the graphite in nodular cast iron rather than the flakes graphite shape in grey iron. Various grades are produced by controlling the matrix structure surrounding the graphite in its structure via casting processes or by heat treatment operation. Alloy additions may be utilized in controlling the matrix structure of cast iron or to make this cast iron response to heat treatment operation (George, 2011). Austempered ductile iron (ADI) has emerged as a promising engineering material during the last thirty years because of its unique mechanical properties, which includes high tensile strength, good impact toughness, and good fatigue resistance under dynamic loading conditions. Having been adjudged to 
be an economical replacement for wrought or forged steel, it has been used very often in automobile, mining, railway and agricultural machinery sectors (Seshan, 1998). However, the abrasion resistance of ADI is not very satisfied, which has engendered the development of a new type of ADI, called Carbidic ADI or CADI (Liu et al., 2010). CADI contains a certain amount of carbides dispersed in its ausferrite matrix, which gives it higher hardness and improved abrasion resistance when compared with ADI. Its potential application areas are construction and mining components, railroad, agricultural and defense structures, which need superior properties, especially abrasive wear resistance (Yang \& Putatunda, 2005). However, its relatively low toughness, caused by coarse carbides in the material, has a negative influence on the abrasion resistance of CADI and thus limits its applications. Obtaining an optimum balance between abrasion resistance and toughness through microstructure modification is an essential demand for the development of this material. Studies have been reported on introduction and stabilization of carbides in cast iron, which include reducing the quantity of graphitizing elements (in particular Silicon), introducing carbide stabilizers, such as $\mathrm{Cr}$, Mo and $\mathrm{Ti}$, and controlling the cooling rate during solidification (Hayrynen \& Brandenburg, 2002). These methods indeed favour the formation and stabilization of carbides. However, the stabilized carbides preferentially form at the eutectic cell boundaries in a cellular or fishbone morphology, which are detrimental to the toughness of CADI. Furthermore, because these carbides are stabilized by alloying elements, and their morphology and distribution could not be changed easily by heat treatment. Ways of controlling the morphology and size of these carbides has remain an intractable and vital issue to researchers in the field of engineering (Zhou et al., 2012).

\section{Experimental Procedure}

\subsection{Sample Preparation}

Charge calculation was carried out to determine the amounts of alloying elements in gram to be added using the formula stated in equation 1 (Khanna, 2009; Soiński \& Góraj, 2009; Ziółkowskia \& Wrona, 2007).

Amount of alloying element is given as

(Required Amount) - (Amount in the base metal) $\mathrm{x}$ (Total wt.of the Charge)

\subsubsection{Melting}

The material used in this study were locally sourced from the credible chemical companies and standard laboratories.

Indirect electric arc furnace of $3 \mathrm{~kg}$ capacity was used for the melting of the charge materials. The required quantity of the charging materials was weighed and charged into the furnace. Grey cast iron scraps of known compositions were first charged and heated to the temperature of $1140^{\circ} \mathrm{C}$ before the adding the alloy elements. Carbon (II) tetrachloride powder was added as a degasser. Nitrided ferro-manganese ( $\mathrm{Fe}-75 \% \mathrm{MnN}$ ) was added to enrich the nitrogen content of the melt as well as to neutralize the harmful effect of the Sulphur from the charge. Pouring was done at $1350^{\circ} \mathrm{C}$ into a sand mould. The cast alloys rods were $12 \mathrm{~mm}$ diameter by $180 \mathrm{~mm}$ length (Anish, 2002).

In all cases the melts were nodulized with Fe-Si-Mg (9wt.\% Mg) and inoculated with Fe-Si (75wt.\% Si). Six alloys of ductile iron were obtained, with approximately $0,0.096,0.192,0.288,0.384$ and $0.480 \mathrm{wt} . \% \mathrm{Sb}$. The samples obtained from the cast alloys were then heat-treated to austenitizing temperature of $910{ }^{\circ} \mathrm{C}$ and held for 1 hour in a muffle furnace followed by an austempering step in an equal mixture of sodium nitrate-potassium nitrate salt bath at austempering temperatures of $300^{\circ} \mathrm{C}$ and $325^{\circ} \mathrm{C}$ for period of $1-3 \mathrm{hrs}$ respectively.

\subsection{Chemical and Microstructural Examination, Microstructural Analysis, Chemical Analysis}

The chemical compositions of the produced alloys were determined using Spark Emission Optic Spectrometer (Spectro-pro MAXx-LMM06) with a DV6 excitation source. Test pieces' surface were ground to ensure flatness before mounting them one after the other on the sparking point of the spectrometer and the button was pressed. After 30-40 seconds composition was displayed on the monitor screen (Youping et al., 2013).

The microstructures of the produced alloys were evaluated by using light reflected optical metallurgical microscope (Axio-Observer A1m) complimented with FESEM Scanning Electron Microscope with an EDX module, in order to evaluate the microstructural examination of the alloys with respect to antimony element content in the produced alloys. Metallographic sample preparation for optical microscopy examination was carried out using standard techniques for cutting, grinding and polishing before etching the prepared samples with $2 \%$ Nital before examination (Khanna, 2009). 


\subsubsection{X-Ray Diffraction (XRD)}

Analysis was performed on the produced CADI samples. The samples were placed in a Lucite holder on the goniometry of the Shimadzu XDS $2400 \mathrm{H}$ diffractometer. The diffraction beam monochromator operated at $40 \mathrm{KVA}$ and a current of $30 \mathrm{~mA}$ with the 20 values varying from $0^{\circ}$ to $140^{\circ}$ with step size of $0.02^{\circ}$ for 120 minutes to create X-ray patterns with enough intensity to produce lines to identify with planes and compounds present in the samples. The plane and the compounds were identified using joint committee on powder diffraction standard (JCPDS).

\section{Results and Discussion}

\subsection{Chemical and Microstructural Characterization}

Table 1. Chemical composition of the six different alloys, 1, 2, 3, 4, 5 and 6 , showing in all cases an approximately hyper-eutectic composition (carbon equivalent, C.E is 4.43)

\begin{tabular}{lllllllllllll}
\hline $\mathbf{N o}$ & $\mathbf{F e}$ & $\mathbf{C}$ & $\mathbf{S i}$ & $\mathbf{M n}$ & $\mathbf{C r}$ & $\mathbf{N i}$ & $\mathbf{C u}$ & $\mathbf{M g}$ & $\mathbf{S b}$ & $\mathbf{S}$ & $\mathbf{P}$ & $\mathbf{C . E}$ \\
\hline $\mathbf{1}$ & 89.39 & 3.62 & 2.42 & 0.58 & 2.6 & 0.60 & 0.69 & 0.06 & - & 0.004 & 0.040 & 4.43 \\
$\mathbf{2}$ & 89.33 & 3.62 & 2.40 & 0.57 & 2.61 & 0.61 & 0.65 & 0.07 & 0.096 & 0.005 & 0.041 & 4.43 \\
$\mathbf{3}$ & 89.24 & 3.62 & 2.41 & 0.57 & 2.62 & 0.62 & 0.61 & 0.07 & 0.192 & 0.005 & 0.042 & 4.44 \\
$\mathbf{4}$ & 89.19 & 3.63 & 2.40 & 0.56 & 2.60 & 0.60 & 0.62 & 0.07 & 0.288 & 0.005 & 0.042 & 4.44 \\
$\mathbf{5}$ & 89.10 & 3.62 & 2.41 & 0.56 & 2.63 & 0.61 & 0.62 & 0.06 & 0.384 & 0.005 & 0.040 & 4.44 \\
$\mathbf{6}$ & 88.97 & 3.62 & 2.40 & 0.58 & 2.62 & 0.60 & 0.63 & 0.06 & 0.480 & 0.004 & 0.041 & 4.43 \\
\hline
\end{tabular}

Chemical composition for the different heats evaluated (wt.\%).

Table 2. Interpretation of the Codes Used To Represent The Samples For Microstructural Analysis

\begin{tabular}{|c|c|}
\hline Codes & Interpretation \\
\hline $\mathrm{C} 1$ & Plate 1: Control sample - 0wt. $\%$ Sb content \\
\hline $\mathrm{C} 2$ & Plate 2: produced sample with 0.096wt.\% Sb content (Carbidic Ductile Iron) \\
\hline $\mathrm{C} 3$ & Plate 3: produced sample with $0.192 \mathrm{wt} \%$ Sb content (Carbidic Ductile Iron) \\
\hline $\mathrm{C} 4$ & Plate 4: produced sample with $0.288 w t . \%$ Sb content (Carbidic Ductile Iron) \\
\hline C 5 & Plate 5: produced sample with 0.384wt.\% Sb content (Carbidic Ductile Iron) \\
\hline C 6 & Plate 6 : produced sample with $0.480 \mathrm{wt} . \%$ Sb content (Carbidic Ductile Iron) \\
\hline $\mathrm{CHO} 1$ & Plate 7: Control Carbidic Austempered Ductile Iron (CADI) held for 1hour \\
\hline A H1 & Plate 8: produced $0.096 \mathrm{wt} . \% \mathrm{Sb}$ CADI held for 1 hour \\
\hline B H1 & Plate 9: produced 0.192wt.\% Sb CADI held for 1hour \\
\hline C H1 & Plate 10 : produced $0.288 \mathrm{wt} . \% \mathrm{Sb}$ CADI held for 1 hour \\
\hline D H1 & Plate 11: produced $0.384 \mathrm{wt} . \% \mathrm{Sb}$ CADI held for 1 hour \\
\hline E H1 & Plate 12: produced $0.480 \mathrm{wt} . \% \mathrm{Sb}$ CADI held for 1 hour \\
\hline $\mathrm{C} \mathrm{H} 02$ & Plate 13: produced control CADI held for 2 hours \\
\hline A H2 & Plate 14: produced $0.096 \mathrm{wt} . \% \mathrm{Sb}$ CADI held for 2 hours \\
\hline B H2 & Plate 15: produced $0.192 \mathrm{wt} . \% \mathrm{Sb}$ CADI held for 2 hours \\
\hline $\mathrm{C} \mathrm{H} 2$ & Plate 16: produced $0.288 \mathrm{wt} . \% \mathrm{Sb}$ CADI held for 2 hours \\
\hline D H2 & Plate 17: produced $0.384 \mathrm{wt} . \% \mathrm{Sb}$ CADI held for 2 hours \\
\hline $\mathrm{E} \mathrm{H} 2$ & Plate 18: produced $0.480 \mathrm{wt} . \% \mathrm{Sb}$ CADI held for 2 hours \\
\hline $\mathrm{C} \mathrm{H03}$ & Plate 19: produced control CADI held for 3 hours \\
\hline A H3 & Plate 20: produced 0.096wt.\% Sb CADI held for 3 hours \\
\hline B H3 & Plate 21: produced $0.192 \mathrm{wt} . \% \mathrm{Sb}$ CADI held for 3 hours \\
\hline $\mathrm{CH} 3$ & Plate 22: produced $0.288 \mathrm{wt} . \% \mathrm{Sb}$ CADI held for 3 hours \\
\hline D H3 & Plate 23: produced $0.384 \mathrm{wt} . \% \mathrm{Sb}$ CADI held for 3 hours \\
\hline E H3 & Plate 24: produced $0.480 \mathrm{wt} . \% \mathrm{Sb}$ CADI held for 3 hours \\
\hline C H031 & Plate 25: produced control CADI held for 1 hour \\
\hline A H31 & Plate 26: produced $0.096 \mathrm{wt} . \% \mathrm{Sb}$ CADI held for 1 hour \\
\hline B H31 & Plate 27: produced $0.192 \mathrm{wt} . \%$ Sb CADI held for 1 hour \\
\hline C H31 & Plate 28: produced $0.288 \mathrm{wt} . \% \mathrm{Sb}$ CADI held for 1 hour \\
\hline D H31 & Plate 29: produced $0.384 \mathrm{wt} . \% \mathrm{Sb}$ CADI held for 1 hour \\
\hline E H31 & Plate 30: produced $0.480 \mathrm{wt} . \%$ Sb CADI held for 1 hour \\
\hline
\end{tabular}




\begin{tabular}{|c|c|}
\hline Codes & Interpretation \\
\hline C H013 & Plate 31: produced control CADI for held 2hours \\
\hline А H32 & Plate 32: produced $0.096 \mathrm{wt} . \% \mathrm{Sb}$ CADI held for 2 hours \\
\hline B H32 & Plate 33: produced 0.192wt. \% Sb CADI held for 2 hours \\
\hline $\mathrm{C} \mathrm{H} 32$ & Plate 34: produced $0.288 \mathrm{wt} . \% \mathrm{Sb}$ CADI held for 2 hours \\
\hline D H32 & Plate 35: produced $0.384 \mathrm{wt} . \% \mathrm{Sb}$ CADI for 2 hours \\
\hline E H32 & Plate 36: produced $0.480 \mathrm{wt} . \% \mathrm{Sb}$ CADI held for 2 hours \\
\hline $\mathrm{C} 0 \mathrm{H} 33$ & Plate 37: produced control CADI held for 3 hours \\
\hline A H33 & Plate 38: produced 0.096wt.\% Sb CADI held for 3 hours \\
\hline В H33 & Plate 39: produced 0.192wt.\% Sb CADI held for 3 hours \\
\hline C H33 & Plate 40: produced $0.288 \mathrm{wt} . \%$ Sb CADI held for 3 hours \\
\hline D H33 & Plate 41: produced $0.384 \mathrm{wt} . \%$ Sb CADI held for 3 hours \\
\hline E H33 & Plate 42: produced $0.480 \mathrm{wt} \%$ Sb CADI held for 3 hours \\
\hline SEM 1 & Plate 43: produced Control Carbidic Ductile Iron \\
\hline SEM 2 & Plate 44: produced 0.096wt.\% Sb Carbidic Ductile Iron (CDI) \\
\hline SEM 3 & Plate 45: produced 0.192wt. \% Sb CDI \\
\hline SEM 4 & Plate 46: produced $0.288 \mathrm{wt} . \% \mathrm{Sb}$ CDI \\
\hline SEM 5 & Plate 47: produced $0.384 \mathrm{wt} . \% \mathrm{Sb}$ CDI \\
\hline SEM 6 & Plate 48: produced $0.480 \mathrm{wt} . \% \mathrm{Sb}$ CDI \\
\hline SEM 7 & Plate 49: produced Control CADI austempered at $300^{\circ} \mathrm{C}$ held for 3 hours \\
\hline SEM 8 & Plate 50: produced $0.096 \mathrm{wt} . \% \mathrm{Sb}$ CADI austempered at $300{ }^{\circ} \mathrm{C}$ held for 3 hours \\
\hline SEM 9 & Plate 51: produced $0.192 \mathrm{wt} . \% \mathrm{Sb}$ CADI austempered at $300{ }^{\circ} \mathrm{C}$ held for 3 hours \\
\hline SEM 10 & Plate 52: produced $0.288 \mathrm{wt} . \% \mathrm{Sb}$ CADI austempered at $300^{\circ} \mathrm{C}$ held for 3 hours \\
\hline SEM 11 & Plate 53: produced $0.384 \mathrm{wt} . \%$ Sb CADI austempered at $300{ }^{\circ} \mathrm{C}$ held for 3 hours \\
\hline SEM 12 & Plate 54: produced $0.480 \mathrm{wt} . \% \mathrm{Sb}$ CADI austempered at $300{ }^{\circ} \mathrm{C}$ held for 3 hours \\
\hline SEM 13 & Plate 55: produced Control CADI austempered at $325^{\circ} \mathrm{C}$ held for 3hours \\
\hline SEM 14 & Plate 56: produced $0.096 \mathrm{wt} . \% \mathrm{Sb}$ CADI austempered at $325^{\circ} \mathrm{C}$ held for 3 hours \\
\hline SEM 15 & Plate 57: produced $0.192 \mathrm{wt} . \%$ Sb CADI austempered at $325^{\circ} \mathrm{C}$ held for 3 hours \\
\hline SEM 16 & Plate 58: produced $0.288 \mathrm{wt} . \% \mathrm{Sb}$ CADI austempered at $325^{\circ} \mathrm{C}$ held for 3 hours \\
\hline SEM 17 & Plate 59: produced $0.384 \mathrm{wt} . \% \mathrm{Sb}$ CADI austempered at $325^{\circ} \mathrm{C}$ held for 3 hours \\
\hline SEM 18 & Plate 60: produced $0.480 \mathrm{wt} . \%$ Sb CADI austempered at $325^{\circ} \mathrm{C}$ held for 3 hours \\
\hline
\end{tabular}

P stands for Pearlite, SC stands for secondary carbide, BC stands for blocky carbide, G stands for graphite, GC stands for granular carbide and CC stands for cellulose carbide.
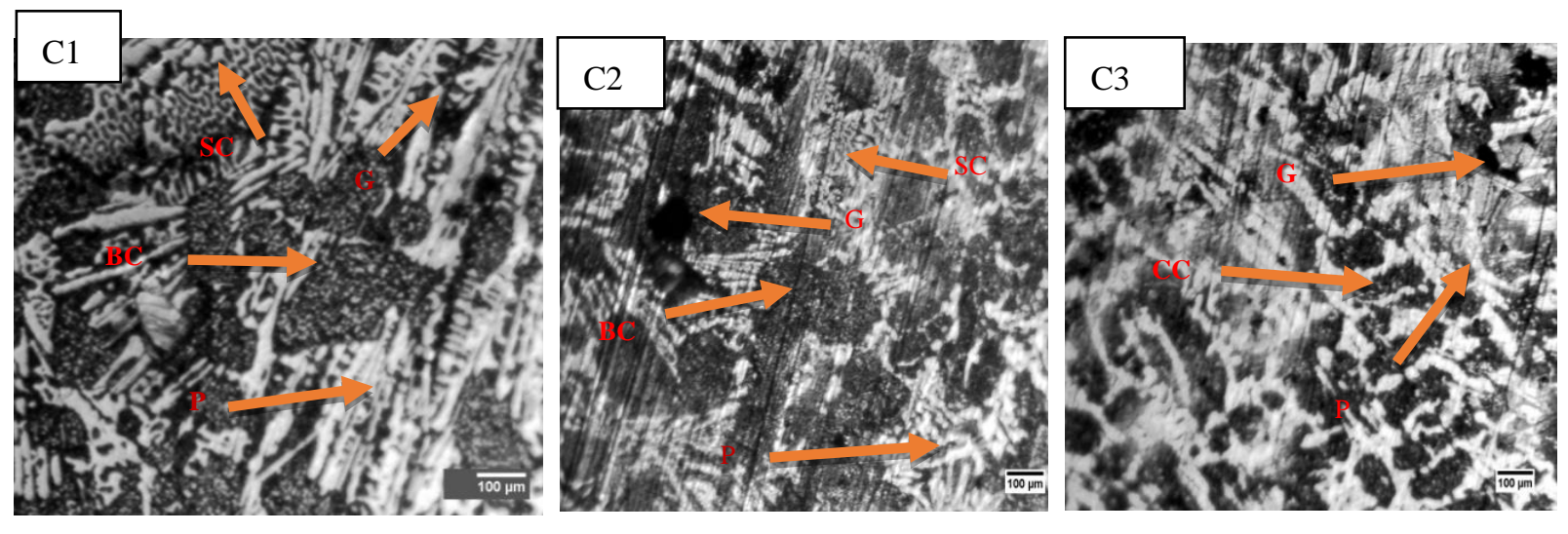

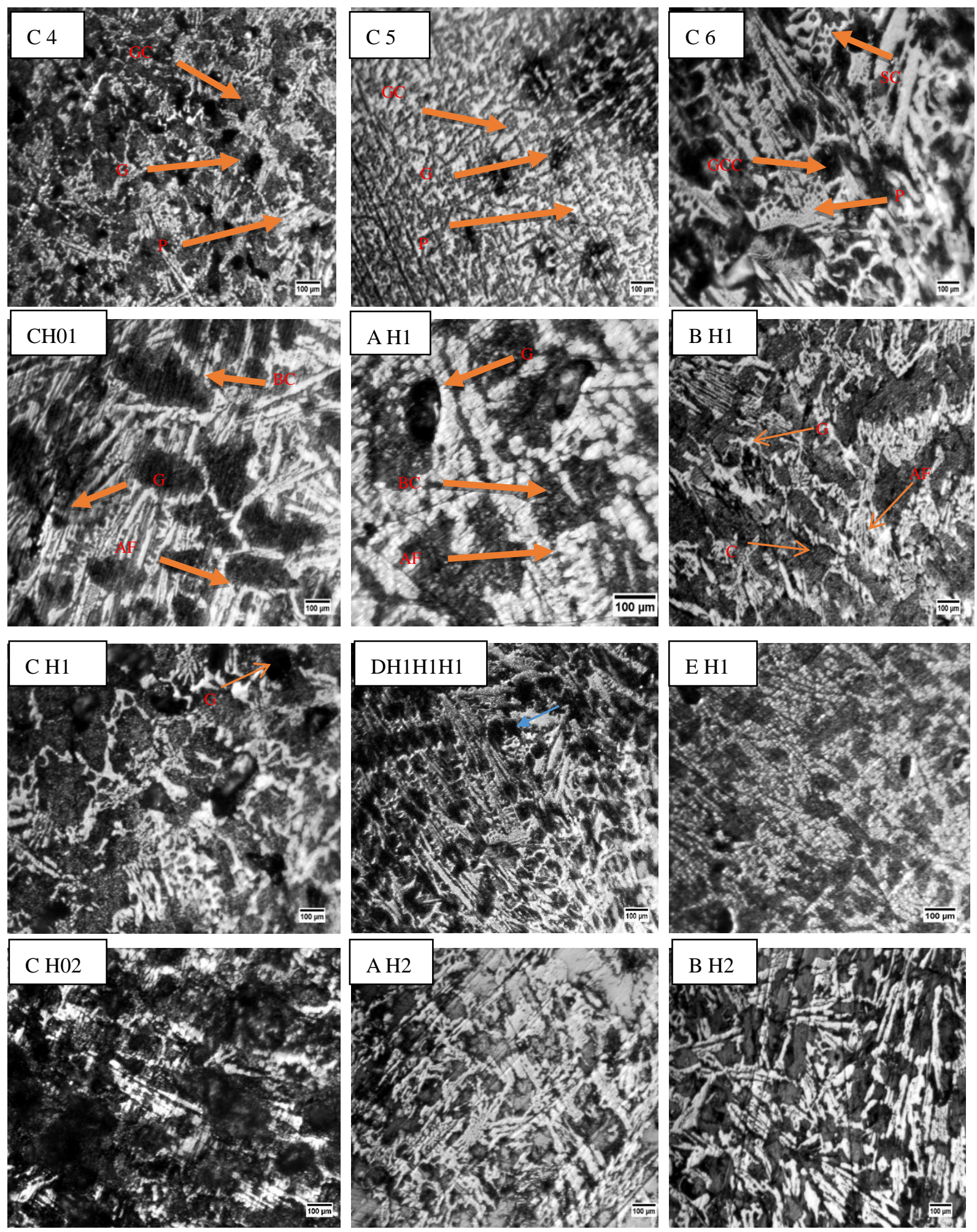

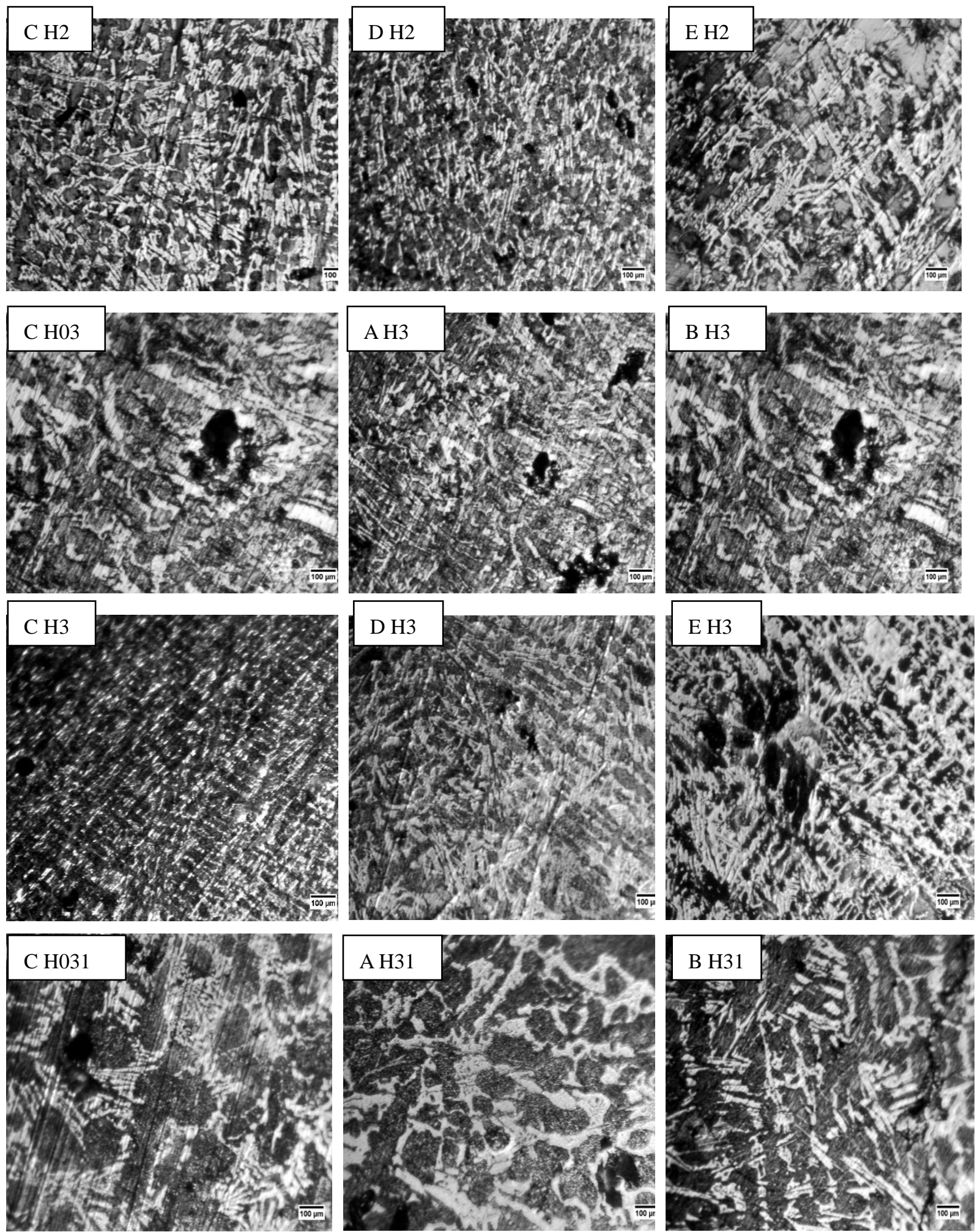

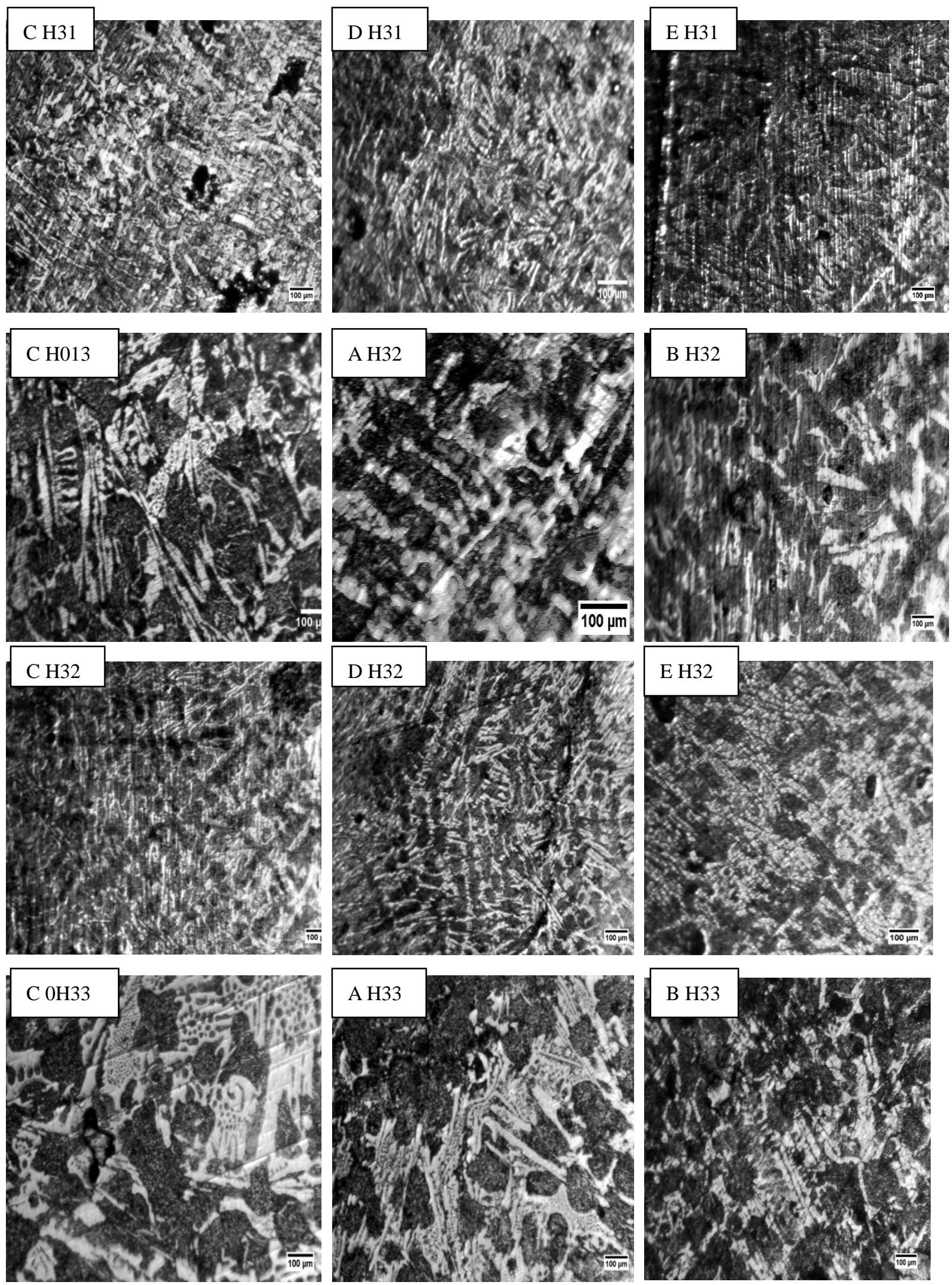

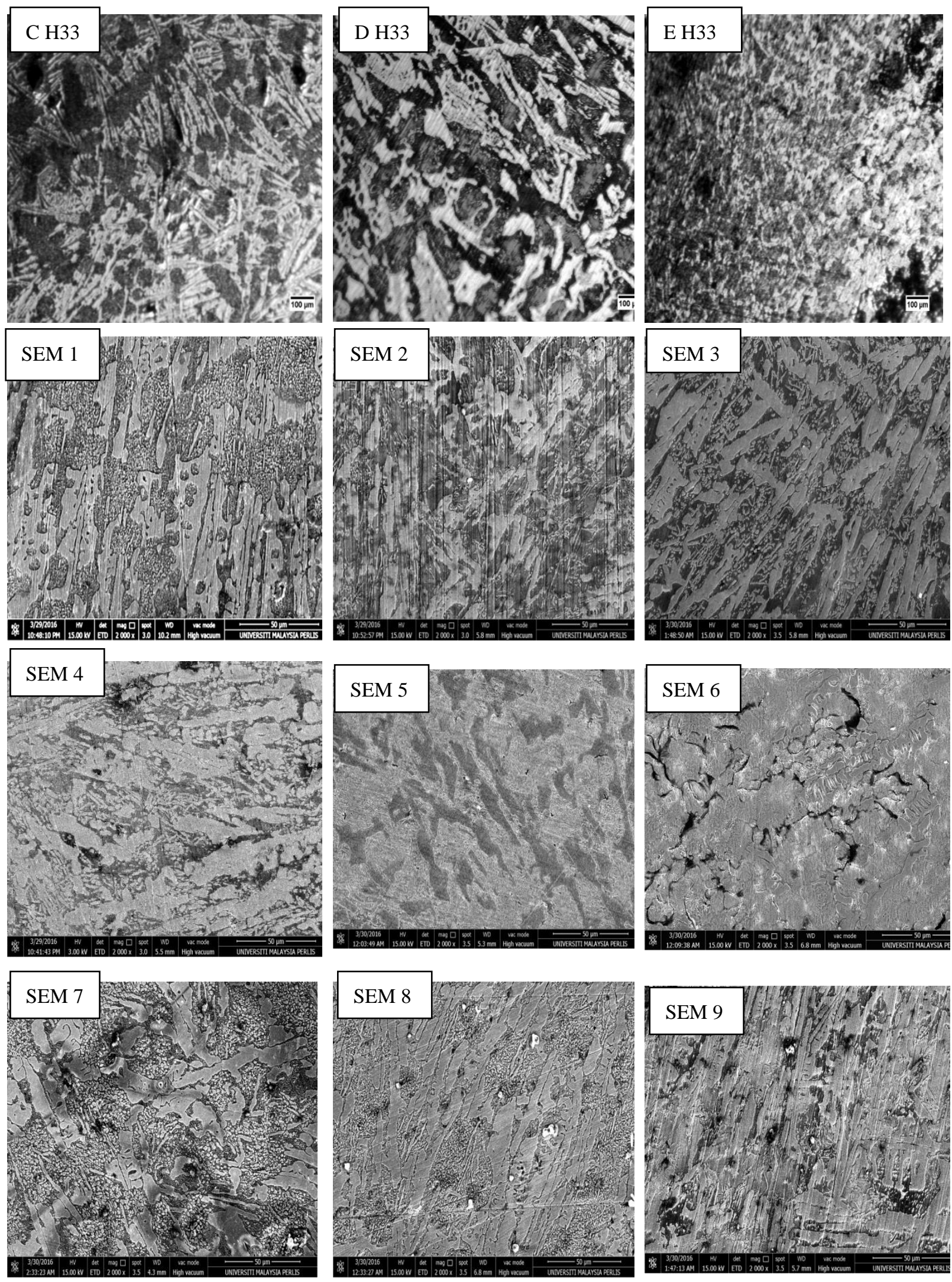

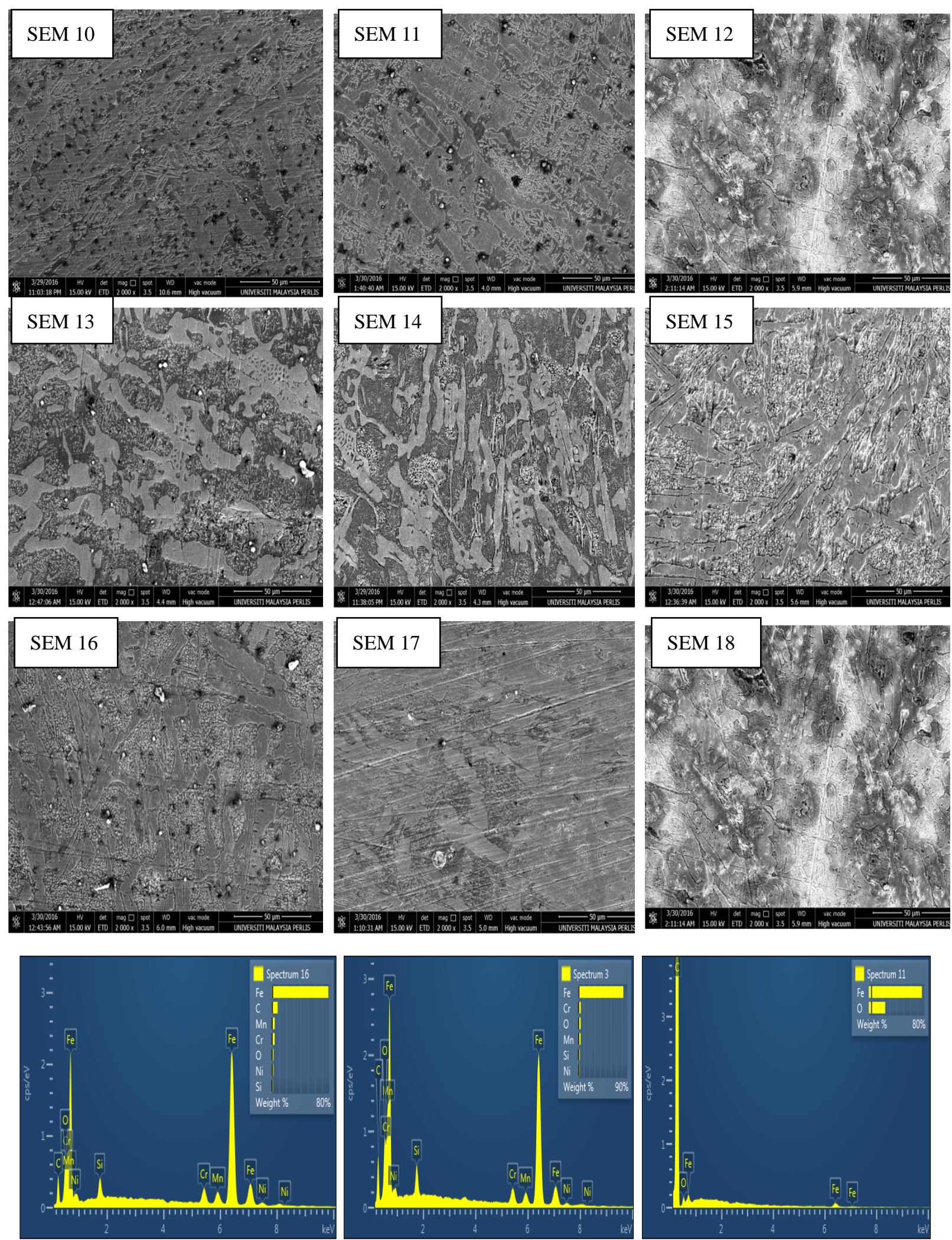

Figure 1. Optical micrographs (Magnification used for all the samples are x 200)

\subsection{X-Ray Diffraction Analysis}

The XRD pattern of carbidic austempered ductile iron (with and without antimony element) austempered at temperatures of $300^{\circ} \mathrm{C}$ and $325^{\circ} \mathrm{C}$ and periods of 1,2 and 3 hours are shown in Figure below. 
In the XRD pattern, sharp peaks were seen, showing that the alloys were crystalline in structure. It was also observed that as the peak angles increase, the inter-planar distance (d) decreases for all the samples.

X-Ray diffraction (XRD) Analysis was performed on the produced CADI samples. The samples were placed in a Lucite holder on the goniometry of the Shimadzu XDS $2400 \mathrm{H}$ diffractometer. The diffraction beam monochromator operated at 40KVA and a current of $30 \mathrm{~mA}$ with the 20 values varying from $0^{\circ}$ to $140^{\circ}$ with step size of $0.02^{\circ}$ for 120 minutes to create X-ray patterns with enough intensity to produce lines to identify with planes and compounds present in the samples. The plane and the compounds were identified using joint committee on powder diffraction standard (JCPDS).

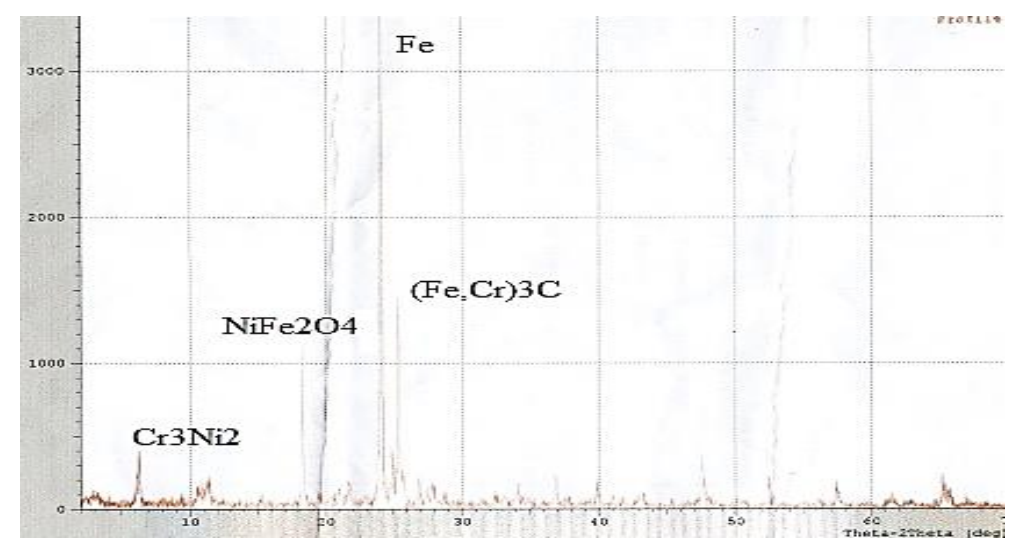

Figure 2 .

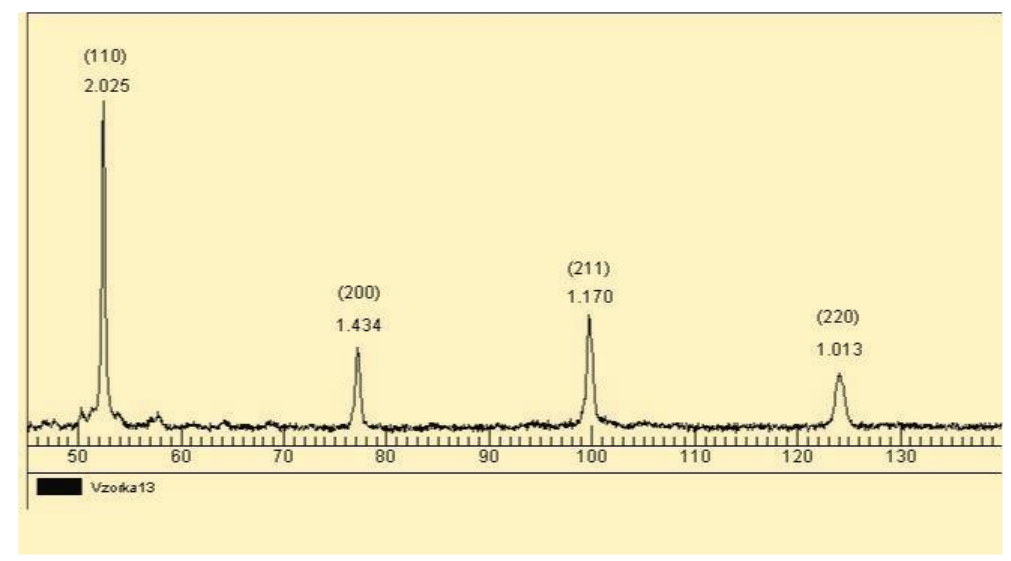

Figure 3.

Table 2.

\begin{tabular}{lllll}
\hline Peak & 28/degree & Plane & d-Valve $\left(\mathbf{A}^{\circ}\right)$ & Intensity $(\boldsymbol{\%})$ \\
\hline 1 & 46.72 & 023 & 2.715 & 168 \\
2 & 50.26 & 100 & 2.348 & 310 \\
3 & 52.74 & 110 & 2.025 & 1870 \\
4 & 57.82 & 111 & 1.729 & 192 \\
5 & 64.68 & 112 & 1.586 & 197 \\
6 & 77.64 & 200 & 1.434 & 656 \\
7 & 79.01 & 202 & 1.381 & 113 \\
8 & 90.99 & 210 & 1.206 & 137 \\
9 & 99.83 & 211 & 1.170 & 823 \\
10 & 105.02 & 212 & 1.094 & 178 \\
11 & 124.49 & 220 & 1.013 & 513 \\
12 & 136.09 & 311 & 0.643 & 125 \\
\hline
\end{tabular}


Table 3.

\begin{tabular}{ll}
\hline Compound & Formula \\
\hline Manganese carbide & $\mathrm{Mn}_{3} \mathrm{C}$ \\
Carbon & $\mathrm{C}$ \\
Chromium carbide & $\mathrm{Cr}_{7} \mathrm{C}_{3}$ \\
Cementite & $\mathrm{Fe}_{3} \mathrm{C}$ \\
Tongbaite & $\mathrm{Cr}_{3} \mathrm{C}_{2}$ \\
Chromium carbide & $\mathrm{Cr}_{23} \mathrm{C}_{6}$ \\
Isovite & $(\mathrm{Cr}, \mathrm{Fe})_{23} \mathrm{C}_{6}$ \\
Ferrochrome & $\mathrm{FeCr}$ \\
Silicon carbide, Iron Carbide & $\mathrm{SiC}, \mathrm{FeC}$ \\
\hline
\end{tabular}

\section{Carbides in Metal Base}

From the XRD result, it was observed that the chromium element in the produced CADI reacted with carbon in the grey cast iron scraps used, to formed interstitial phases complex structure (carbides). This was possible because the ratio of carbon atomic radius $(0.071 \mathrm{~nm})$ to that of the atomic radius of chromium $(0.12 \mathrm{~nm})$ is higher than 0.59 or (Branislav et al., 2010).

Also from the XRD results obtained from the samples, more than two different types of carbides were revealed in the samples with different crystal lattices. The chromium present in the cast iron crystallized in a regular, hexagonal $\left(\mathrm{Cr}_{7} \mathrm{C}_{3}\right)$ and as well as in rhombic $\left.\mathrm{Fe}_{3} \mathrm{C}\right)$ system. Alloyed carbide $(\mathrm{Cr}, \mathrm{Fe})_{7} \mathrm{C}_{3}$ was also seen in the XRD results of the CADI samples, secondary chromium carbide with dissolved iron $(\mathrm{Cr}, \mathrm{Fr})_{23} \mathrm{C}_{6}$ was also revealed in the produced CADI samples. The manganese did not react with iron the cast iron to form separate carbide.

The matrix contains regions of pearlite in predominantly austenite matrix and some secondary carbides. There was no evidence of complex regular carbide.

The presence of the primary carbides indicates that the produced CADI is of hypereutectic composition (Nelson, 2010) which collaborates the carbon equivalent value calculated for he samples (which is greater than $4.3 \mathrm{wt} . \% \mathrm{C}$, (4.44). there are very limited number of what could be typically classified eutectic carbide. The presence of eutectic carbides shows that the cast samples undergone inoculation.

The phase constituents and composition were quantified by XRD and EDS respectively in line with the work of Radzikowska (2005).

Table 1 shows the chemical compositions of the base metal (grey cast iron) used for this work. It was observed that the grey cast iron, has a carbon equivalent value of 4.43. It is hyper-eutectic because, cast iron having carbon equivalent below $4.3 \%$ is hyper-eutectic while above $4.3 \%$ is hyper-eutectic (Khanna, 2009). It is a class 30 grey cast iron, is $3.4-3.7 \% \mathrm{C}, 0.06-0.15 \% \mathrm{~S}, 2.1-2.6 \% \mathrm{Si}, 0.45-1.0 \% \mathrm{Mn}, 0.03-0.2 \% \mathrm{P}, 0.03-0.35 \% \mathrm{Cu}$ and 0.004-0.08\% Cr (Anish, 2002).

The addition of chromium decreases the volume of the graphites and formed carbides (Hincley et al., 2008). Pearlitic matrix gives high wear resistance than ferritic matrix according to Marinov (2007).

Pearlitic matrix instead of ferrite matrix was formed to accommodate phases such as carbides according to Khanna (2009) and Agarwal et al. (2007).

It has been observed that those alloys with high wear resistance values have low rate of wear (Ogunsoye et al., 2013).

\subsection{Carbide Morphology}

Table 4. Calculated Grain Sizes of the Produced CADI Samples

\begin{tabular}{llll}
\hline S/N & SAMPLE CODE & Calculated Grain Sizes & Calculated Standard Deviation \\
\hline 1 & C1 & $19.18 \mu \mathrm{m}$ & \pm 0.0025 \\
2 & C2 & $17.43 \mu \mathrm{m}$ & \pm 0.0040 \\
3 & C3 & $10.48 \mu \mathrm{m}$ & \pm 0.1800 \\
4 & C4 & $8.48 \mu \mathrm{m}$ & \pm 0.0430 \\
5 & C5 & $3.60 \mu \mathrm{m}$ & \pm 0.0600 \\
6 & C6 & $12.59 \mu \mathrm{m}$ & \pm 0.1900 \\
\hline
\end{tabular}


The optical micrographs obtained from the produced samples containing vary amount of antinomy element are presented in Figures 1-60. Small size dispersed graphite nodules and alloyed carbides immersed in an ausferrite matrix (fine acicular ferrite and high carbon austenite) which is typical of CADI microstructure (Sun et al., 2012). There are visible changes on the morphology, size and the amount of carbides with the varied micro-quantity of antimony element. For the produced sample without antinomy element addition, there all coarse primary carbides, with blocky morphologies, which have also been reported by other researchers (Laino, Sikora, \& Dommarco, 2008; Sun et al., 2012). After the addition of antimony element, it was observed that the coarse blocky carbides reduce in size these coarse carbides become replaced by finer granular carbides when antinomy contents of $0.096 \mathrm{wt} . \%$ to $0.384 \mathrm{wt} . \%$ were added, the primary alloyed carbide size deceases from $19 \mu \mathrm{m}$ to $3.6 \mu \mathrm{m}$. Beyond the $0.388 \mathrm{wt} . \%$ antimony content, the carbide size increases to approximately $60 \mu \mathrm{m}$, Indicating that $0.38 \mathrm{wt} \% \mathrm{Sb}$ contents the critical content. The granular carbide is beneficial to toughness and fatigue crack propagation resistance, compare with blocky coarse carbide (Sun et al., 2012). The primary carbide likely crystallizes at the austenite-liquid phase boundary. The antimony element added may have preferentially position itself at the interface between austenite phase and carbides, thereby reduce the continuous growth of primary carbides. The addition antimony element may have also served as an inoculant for the formation of finer primary carbides due to the heterogeneous nucleation mechanism.

The antinomy element could have reduced the surface tension of the melt, so encouraging granular growth and stabilizing the granular interface by preventing the growth of any micro perturbation on the surface. It was observed that right quantities of antimony element assisted in refining the alloyed carbides, but excessive antimony element led to much increase in the size of the carbides.

\section{Ausferrite Matrix}

The ausferrite has acicular ferrite and retained austenite. This retained ausferrite played important role in the toughness of the sample. The influence of antimony addition on the austenite fraction was found to increase to $30 \%$ as calculated from the intensives values obtained from the XRD result of the produced CADI samples. Using equation 2, The carbon content in the ausferrite phase increased form 5.4\% carbon content in austenite to $8.8 \%$ carbon content in austenite by the addition of antimony. And the higher the carbon content in the austenite, the more stable the austenite (Sun et al., 2012).

$$
a_{\gamma}=0.3548+0.0044 C_{\gamma}
$$

\section{Conclusion}

1. Microstructural examination of antimony modified CADI has been carried out using Optical metallurgical microscope, Scanning Electron Microscope with EDS, XRD.

2. Primary carbide, few eutectic and secondary carbide were formed in the produced CADI as revealed the xrd results.

3. Blocky carbides were observed in the samples without antimony micro-addition, while granular carbides of varying sizes were observed in the CADI with varying antimony addition in the matrix of pearlite and spiky graphite nodules.

4. After austempering heat treatment operations, the alloyed carbides were seen to be stable, the pearlite matrix was transformed to ausferrite.

5. The observed microstructure was responsible for good balance between wear resistance and impact toughness that can be used for production of agricultural implements.

\section{Conflict of interests}

The authors declare that there is no conflict of interests regarding the publication of this paper.

\section{References}

Agarwal, R. I., Banga, T. R., \& Tahil, M. (2007). Foundry Engineering. Hanna publishers.

Anish, T. V. (2002). Age strengthening of gray cast Iron: Alloying effects and kinetic study. American Foundry Society Transactions, (2-120), 995-1002.

George, M. G. (2011). American Foundry Society Technical Department Publication, Professional Metallurgical Services Unit... North Penny Lane, Schaumburg (pp. 1-5).

Gumienny, G. (2013). Effect of the Carbides and Matrix on the Wear Resistance of Nodular Cast Iron. Archives of Foundry Engineering, 13(3), 25-29. 
Hayryen, K. L., Brandenberg, K. R., \& Kough, J. R. (2002). Applications of ADI. American Foundry Society Transactions, 1-10.

Hinckley, B., Dolman, K. F., Wuhrer, R., Yeung, W., \& Ray, A. (2008). SEM Investigation of Heat Treated High-Chromium Cast Irons. Materials Forum, 32, 55-71.

Laino, S., Sikora, J. A., \& Dommarco, R. C. (2008). Development of Wear Resistant Carbidic Austempered Ductile Iron (CADI). Journal of Wear, 265, 1-7.

Liu, Z., Chen, W. P., \& Du, Y. (2012). Influence of Cooling Rate on Antimony Addition content on Graphite Morphology and Mechanical Properties of a Ductile Iron. China Foundry, 9(2), 114-118.

Nedeljković, B., Lazić, V., Aleksandrović, S., BožidarKrstić, Mutavdžić, M., Milosavljević, D., \& Đorđević, M. (2010). Influence of the Carbide Type on Tribological Properties of the Hard-Faced Layers, Association of Metallurgical Engineers of Serbia, Scientific paper. MJoM, 16(2), 77- 90.

Nelson, G. D. (2010). The Influence of Microstructure on the Corrosion and Wear Mechanisms of High Chromium White Irons in Highly Caustic Solutions. School of Mechanical Engineering, the University of Adelaide South Australia.

Ogunsoye, J. O., Talabi, S. I., Olumuyiwa, I. A., \& Afemefuna, T. (2013). Effect of Silicon Addition on the Wear Properties of Grey Cast Iron. Journal of Minerals and Materials Characterization and Engineering, 1, 61-67.

Radzikowska, M. J. (2005). Metallography and Microstructures of Cast Iron. ASM Handbook, 9, 566-587. Retrieved from http://www.asminternational.org/bookstore

Seshan, S. (1998). Austempered Ductile Iron-The Under Exploited Wonder Cast Iron. Indian Foundry Journal October, 84-92.

Soiński, M. S., \& Góraj, J. (2009). The Influence of Cerium Mixture Addition on the Structure of Cast Iron containing about 5\% Aluminium. Archives of Foundry Engineering, 9(4), 215-218.

Sun, X. G., Wang, Y., Li, D. Y., \& Wang, G. D. (2013). Modification of Carbidic Austempered Ductile Iron with Nano Ceria for Improved Mechanical Properties and Abrasive Wear Resistance. Journal of Wear, 301, 116-121.

Tiedje, N. S. (2010). Solidification, Processing and Properties of Ductile Cast Iron. Journal of Materials Science and Technology, 26(5), 505-514.

Yang, J., \& Putatunda, S. K. (2005). Effect of Microstructure on Abrasion Wear Behavior of Austempered Ductile Cast Iron (ADI) Processed by a Novel Two-step Austempering Process. Journal of Materials Science and Engineering, 406, 217-228.

Youping, M. A., Xlulan, L. J., Yugoa, L. I. U., \& Xlaoving, D. (2013). Microstructures and Properties of Ti-Nb-V-Mo Alloyed High Chromium Cast Iron. Journal of Materials Science, 36(5), 839-844.

Zhou, Y. F., Yang, Y. L., Jiang, Y. W., Yang, J., Ren, X. J., \& Yang, Q. X. (2012). Fe-24wt.\% Cr-4.1wt.\% C Hard-facing Alloys: Microstructure and Carbide Refinement Mechanisms with Ceria Additive (Vol. 72). Journal of Materials Characterization, 77-86.

Ziółkowskia, E., \& Wrona, R. (2007). Using Fuzzy Optimization Method in Calculation of Charge Burden to Correct the Chemical Composition of Metal Melt. Archives of Foundry Engineering, 7(3), 183-186.

\section{Copyrights}

Copyright for this article is retained by the author(s), with first publication rights granted to the journal.

This is an open-access article distributed under the terms and conditions of the Creative Commons Attribution license (http://creativecommons.org/licenses/by/4.0/). 